\title{
THE IN VITRO ANTIMICROBIAL ACTIVITY OF SOME ESSENTIAL OILS FROM AROMATIC PLANTS
}

\author{
EMILIAN IONUT BLEJAN ${ }^{1 \#}$, DANIELA ELENA POPA ${ }^{1 *}$, TEODORA COSTEA $^{1 \#}$, ALINA $^{2,}$ \\ CIOACA $^{2}$, LAURA OLARIU ${ }^{2,3}$, MANUELA GHICA ${ }^{1}$, MARA GEORGESCU $^{4 \#}$, GHEORGHE \\ STANCOV $^{1}$, ANDREEA LETIȚIA ARSENE ${ }^{1}$ \\ I "Carol Davila” University of Medicine and Pharmacy, Faculty of Pharmacy, 6 Traian Vuia Street, 020956, Bucharest, \\ Romania \\ ${ }^{2}$ S.C. Biotehnos S.A., 3-5 Gorunului Street, 075100, Otopeni, Ilfov, Romania \\ ${ }^{3}$ Academy of Romanian Scientists, 54 Splaiul Independenței Street, 050094, Bucharest, Romania \\ ${ }^{4}$ University of Agronomic Sciences and Veterinary Medicine of Bucharest, Faculty of Veterinary Medicine, 59 Mărăşti \\ Boulevard, 011464, Bucharest, Romania
}

*corresponding author: daniela_popa@umfcd.ro

\#Authors with equal contribution.

Manuscript received: December 2020

\begin{abstract}
Essential oils (EOs) are plant secondary metabolites with a wide range of therapeutic effects (antioxidant, antibacterial, antifungal, anti-inflammatory). Thus, this study aims to assess the antibacterial/antifungal activity of six essential oils against Staphylococcus aureus, Escherichia coli strains and Candida albicans yeast, as follows: oregano oil; tea tree oil; a mixture of oils obtained from clove, cinnamon, lime, rosemary and eucalyptus; Frankincense oil; basil oil; black pepper oil. The antimicrobial activity was assessed by means of agar disk diffusion method. Based on the diameter of inhibition zones and the statistical analyses, our results have shown that the $S$. aureus strains were highly susceptible to all types of EOs and the biological effect was similar for oregano and basil essential oils. Regarding E. coli, the oregano, basil and tea tree EOs exerted a significant and similar antibacterial effect, while antifungal activity was reported for the tea tree and basil essential oils. Based on our results, we also identified the main active constituents from the analysed samples that appear to be responsible for the antimicrobial activity, in the context of the multicomponent extract.
\end{abstract}

\section{Rezumat}

Uleiurile esențiale (EO) sunt metaboliți secundari ai plantelor cu o gamă largă de efecte terapeutice (antioxidant, antibacterian, antifungic, antiinflamator). Astfel, acest studiu își propune să evalueze activitatea antibacteriană/antifungică a șase uleiuri esențiale împotriva unor tulpini standard de Staphylococcus aureus, Escherichia coli și Candida albicans: ulei de oregano; ulei de arbore de ceai; amestec de uleiuri obținut din cuișoare, scorțişoară, tei, rozmarin și eucalipt; ulei din rășina speciei Boswellia serrata; busuioc; piper negru. Activitatea antimicrobiană a fost evaluată prin metoda difuzimetrică în agar. Pe baza diametrului zonelor de inhibiție și a analizei statistice, rezultatele noastre au arătat că tulpinile de $S$. aureus sunt sensibile la toate tipurile de EO și efectul biologic a fost similar pentru uleiurile esențiale de oregano și busuioc. În ceea ce privește $E$. coli, uleiurile de oregano, busuioc și arbore de ceai au exercitat un efect antibacterian semnificativ și similar, în timp ce activitatea antifungică a fost raportată pentru uleiurile esențiale de arbore de ceai și busuioc. Pe baza rezultatelor noastre, am identificat, de asemenea, principalii constituenți activi din probele analizate care par a fi responsabile de activitatea antimicrobiană, în contextul fitocomplexului.

Keywords: antimicrobial activity, essential oils, disk diffusion assay, aromatic plants

\section{Introduction}

Essential oils (EOs) are secondary plant metabolites, comprising mainly terpenes (mostly monoterpenes and sesquiterpenes), terpenoids (oxygenated compounds such as phenols, alcohols, aldehydes, ketones or ethers) and aromatic compounds [36, 39]. They are produced and secreted by specialized secretory tissues (glandular trichomes, secretory glands, secretory cavities) diffused onto the surface of aromatic plant organs (flowers, leaves, roots, fruits, bark etc.) $[17,36]$. Essential oils play an important role in adaptation of plants to abiotic stresses (draught, high temperatures, $\mathrm{CO}_{2}$ and ozone levels) and defence against pathogens $[17,36]$. EOs have a high variability of their composition, which is a consequence of both intrinsic (related to plant's maturity, time of harvest, pedoclimatic conditions) and extrinsic factors (extraction methods such as steam distillation, solvent extraction, cold press extraction, enfleurage or supercritical-fluid extraction) [15]. Used for many years in the perfume industry, foodstuffs/beverages and phytotherapy, EOs were proved to be sources of bioactive compounds, with a wide range of therapeutic effects - antioxidant, antibacterial, 
antifungal, anti-inflammatory and cancer chemopreventive activities $[15,17]$.

Due to structural and biological diversity of the essential oils active compounds and due to their antimicrobial potential, EOs are extensively researched among other strategies to fight against bacterial/fungi resistance to antibiotics/antifungal drugs [34].

An important characteristic of essential oils and their components is the hydrophobicity, which enables them to partition with the lipids present in the cell membrane of bacteria and mitochondria, rendering them more permeable, by disturbing the cell structures [16]. This, eventually results in the bacterial cell death, due to leakage of critical molecules and ions. Other mechanisms involved in EOs antimicrobial properties include coagulation of the cytoplasm, reduction of proton motive force, hydrolysis of ATP and decreased ATP synthesis $[4,32]$. According to recent studies, the antifungal properties of EOs are due to inhibition of ergosterol biosynthesis, malate dehydrogenase, mitochondrial ATPase and succinate dehydrogenase activities [9, 27].

Moreover, some compounds modulate drug resistance by targeting efflux mechanisms in several Gramnegative bacteria $[9,12]$. In addition, according to recent published reports, EOs impair the biofilm produced by Gram-positive or Gram-negative bacteria [21].

The aim of this study was the evaluation of antimicrobial effects of several essential oils against a Gram-positive bacteria (Staphylococcus aureus), Gramnegative bacteria (Escherichia coli) and Candida albicans, outlining the main active compounds with antimicrobial properties.

\section{Materials and Methods}

Essential oils

We have used six essential oils (EOs), which were acquired from PlantTherapy ${ }^{\circledR}$, USA. The studied essential oils were organic, with no added synthetic compounds: (1) oregano oil, (2) tea tree oil, (3) a mixture of oils obtained from clove, cinnamon, lime, rosemary, eucalyptus and rosemary, (4) Frankincense oil, (5) basil oil, (6) black pepper oil (Table I). The samples were kept at room temperature, protected from light. The chemical characterization of the EOs by GC-MS (gas chromatography-mass spectrometry) analysis is available on the supplier's website [40].

Table I

Essential oils used in the study

\begin{tabular}{|l|c|l|c|}
\hline \multicolumn{1}{|c|}{ EOs } & Code & \multicolumn{1}{|c|}{ Obtained of } & Origin \\
\hline Oregano essential oil & U1 & Aerial parts of Origanum vulgare L. subsp. vulgaris & Turkey \\
\hline Tea tree essential oil & U2 & Leaves of Melaleuca alternifolia (Maiden \& Betche) Cheel. & Australia \\
\hline $\begin{array}{l}\text { Mixture of lemon, cinnamon, } \\
\text { clove, rosemary and } \\
\text { eucalyptus essential oils }\end{array}$ & $\mathbf{U 3}$ & $\begin{array}{l}\text { Lemon peel (Citrus limonum L. (Osbek.), bark of Chinese cinnamon } \\
\text { (Cinnamomum cassia } \text { (L.) J. Pressi), buds of Eugenia caryophyllus } \text { (L.) } \\
\text { Merrill \& Perry (clove), leaves of Eucalyptus globulus Labill. (eucalyptus), } \\
\text { leaves of Rosmarinus officinalis L. (rosemary) }\end{array}$ & nd \\
\hline Frankincense essential oil & U4 & Resin of Boswellia serrata Roxb. & India \\
\hline Basil essential oil & U5 & Aerial parts of Ocimum basilicum L. & Nepal \\
\hline Black pepper essential oil & U6 & Fruits of Piper nigrum L. & Sri Lanka \\
\hline
\end{tabular}

EOs - essential oils, nd - no data available

Bacterial strains and growth conditions

The microorganisms used in our study were Grampositive bacteria (Staphylococcus aureus ATCC 6538), Gram-negative bacteria (Escherichia coli ATCC 8739) and yeasts (Candida albicans ATCC 10231). These microorganisms were chosen based on their involvement in common human infections. Moreover these strains have shown high resistance to antibiotics or high environmental or antibiotic adaptability. These strains were part of the collection of the Department of Microbiology, SC Biotehnos SA, Bucharest, Romania. All bacterial strains were kept at $-70^{\circ} \mathrm{C}$ in a cryopreservative solution (Microbank, Pro-lab Diagnostics, Richmond Hill, ON, Canada), inoculated overnight in tryptic soy agar and incubated overnight at $30^{\circ} \mathrm{C}$. Subsequently, one colony of each culture was inoculated in brain heart infusion broth and incubated at $30^{\circ} \mathrm{C}$ for $24 \mathrm{~h}$ with shaking $(75 \mathrm{rpm})$, in order to obtain freshly cultured microbial suspensions for further experiments. The density of microbial suspensions was adjusted to the turbidity of a $0.5 \mathrm{McFarland}$ Standard.

\section{Preparation of EOs working solutions}

The analysed essential oils were diluted in 1\% DMSO an amphiphilic molecule that has the ability to dissolve both hydrophilic and lipophilic compounds and whose miscibility with water makes it suitable for biomedical research as previously reported by other authors [13, $29,30]$. The samples were dissolved in $1 \%$ DMSO to obtain final stock solutions of $0.1 \%(1 \mathrm{mg} / \mathrm{mL})$. From each stock solution, volumes of $500 \mu \mathrm{L}$ and $10 \mu \mathrm{L}$ were further diluted with $1 \% \mathrm{DMSO}$ (to a final volume of $1 \mathrm{~mL}$ ), in order to reach concentrations of $0.5 \mathrm{mg} / \mathrm{mL}$ and $0.01 \mathrm{mg} / \mathrm{mL}$.

The antimicrobial activity was determined by means of agar disk diffusion method, widely used for the evaluation of antibacterial/antifungal properties of EOs [20, 29, 38]. 
Agar disk diffusion method

The antibacterial activity of analysed EOs (U1 - U6) was determined with the disk diffusion method according to NCLSS (2002) guidelines [28]. The method consisted in using sterilized Petri dishes $(90 \mathrm{~mm} \emptyset)$ with MüllerHinton agar medium, sown with each of the microbial suspensions $\left(100 \mu \mathrm{L}\right.$ of suspension containing $2 \times 10^{8}$ $\mathrm{CFU} / \mathrm{Ml})$. Subsequently filter paper discs $(8 \mathrm{~mm} \emptyset)$ were placed on the surface of Petri dishes and impregnated with $50 \mu \mathrm{L}$ of the EOs concentrations ( $1 \mathrm{mg} / \mathrm{mL}, 0.5 \mathrm{mg} / \mathrm{mL}$ and $0.01 \mathrm{mg} / \mathrm{mL}$ diluted in $1 \%$ DMSO). Negative controls were prepared using only $1 \%$ DMSO. All Petri dishes were incubated at $37^{\circ} \mathrm{C}$ for 24 hours. All determinations were performed in triplicate. The mean diameter of inhibition halo was measured for each disk, using a calliper rule with a resolution of $0.01 \mathrm{~mm}$.

The effectiveness was classified according to the size of inhibition zones measured as: strongly inhibitory (> $20 \mathrm{~mm})$, moderately inhibitory $(20-12 \mathrm{~mm})$ and with no inhibitory effect $(<12 \mathrm{~mm})$ [20].

Statistical analysis

The results were analysed in spreadsheet software (Microsoft Excel 2007) and presented as means \pm SD (standard deviation). The comparison between samples was performed for each microorganism per tested concentration, using a robust statistical method: singlefactor ANOVA, involving a resampling of the data by the Bootstrap method using the open source software R [22]. With the Bootstrap technique, working hypotheses for ANOVA are no longer mandatory (such as data normality). In this regard, the method increases the accuracy of the results [1]. The post hoc analysis (Bonferroni test) compared the difference of the means with the value 0 ; statistical significance was accepted for alpha level 0.05 . The variations of the confidence intervals (CI 95\%) associated with the difference of the inhibition zone diameters $(\mathrm{mm})$ for each EOs concentration depending on the microorganism, were also determined. If the CI 95\% values were further from zero, the antimicrobial activity of the EOs would differ significantly $(\mathrm{p}<0.05)$. When the CI 95\% contained the zero value, one could not find significant differences between the means, so EOs showed similar antimicrobial effects ( $p>0.05$ ).

Given that essential oils have a complex composition, and therefore the antimicrobial action is the synergistic result of the phytocomplex and not owing to a single active substance, we proposed to use this statistical method to identify common active principles in essential oils with similar antimicrobial activity. In addition, because "similar" activity may refer to low or potent antimicrobial activity, we corroborated the results of the statistical analysis with mathematical observations given by the diameters of the inhibition zones, in order to identify only essential oils with potent antimicrobial activity and therefore, of their active principles common.

\section{Results and Discussion}

In general, according to our results (Table II), the analysed EOs have shown moderate or strong antimicrobial activity based on the diameter of inhibition zones. U3 essential oil (for $1 \mathrm{mg} / \mathrm{mL}$ and $0.5 \mathrm{mg} / \mathrm{mL}$ concentrations) (Table II) has shown the best antibacterial effects against $S$. aureus and E. coli. As previously reported, we assume that this effect is due to the greater diversity of active compounds in its composition and implicitly of additive and synergistic interactions [2].

Taking into account that U3 is a mixture of essential oils with synergistic activity, we have excluded it from our further statistical analysis.

In the case of Staphylococcus aureus, at $1 \mathrm{mg} / \mathrm{mL}$ concentration, the antimicrobial activity varied as follows: U1 > U6 > U5 > U2; oregano essential oil was the most active, followed by black pepper essential oil, basil essential oil and tea tree essential oil.

At $0.5 \mathrm{mg} / \mathrm{mL}$ the antimicrobial activity varied as follows: U5 $\approx \mathrm{U} 1>\mathrm{U} 2>\mathrm{U} 4>\mathrm{U} 6$. Similar results (U1 > U2 > U5) were also obtained for the lowest concentration $(0.01 \mathrm{mg} / \mathrm{mL})$. According to our statistical analysis (Figure 1), for $1 \mathrm{mg} / \mathrm{mL}$ concentration, similar antimicrobial behaviour was recorded for samples U5 and U6 ( $p>0.05$ ); for concentration $0.5 \mathrm{mg} / \mathrm{mL}$, similar antimicrobial behaviour was obtained for samples U5 and U1 ( $\mathrm{p}>0.05$ ) and for $0.01 \mathrm{mg} / \mathrm{mL}$, similar antimicrobial behaviour was obtained for U6 and $\mathrm{U} 4$ samples $(\mathrm{p}>0.05)$. On the other hand, the values of the diameters of the inhibition zones (Table II) revealed potent, similar, antimicrobial activity for U1, U2 and U5 essential oils, regardless the concentration. Samples U4 and U6 did not proved antimicrobial effect at the tested concentrations. The highest antistaphylococcal activity was determined for oregano and basil EOs.

Regarding the antibacterial effects against Escherichia coli, from the statistical data, we acknowledged that for $1 \mathrm{mg} / \mathrm{mL}$ concentration, similar antimicrobial behaviour ( $p>0.05$ ) was recorded for U1, U2 and U5 (Figure 2). The same pattern was also observed for U5 and U2, respectively $\mathrm{U} 6$ and $\mathrm{U} 4$ at $0.5 \mathrm{mg} / \mathrm{mL}(\mathrm{p}>0.05)$. Nevertheless, at $0.01 \mathrm{mg} / \mathrm{mL}$, similar antimicrobial effect was obtained for $\mathrm{U} 2$ and $\mathrm{U} 1$, respectively $\mathrm{U} 6$ and U4 essential oils ( $p>0.05$ ). On the other hand, the diameters of the inhibition zones (Table II) revealed potent, similar and significant antimicrobial activity for U1 (oregano), U2 (tea tree) and U5 (basil) essential oils, regardless the concentration. One again, the samples U4 and U6 did not exert biological action the tested strains 
Table II

Diameters $(\mathrm{mm})$ of growth inhibition zones of analysed essential oils against tested microorganisms

\begin{tabular}{|c|c|c|c|c|}
\hline \multirow{2}{*}{$\begin{array}{c}\text { Essential } \\
\text { oil }\end{array}$} & \multirow{2}{*}{$\begin{array}{c}\text { Concentration } \\
(\mathrm{mg} / \mathrm{mL})\end{array}$} & S. aureus & E. coli & C. albicans \\
\hline & & \multicolumn{3}{|c|}{ Inhibition zone (mm) } \\
\hline \multirow{3}{*}{ U1 } & 1 & $18.45 \pm 0.11$ & $15.11 \pm 0.15$ & $>$ \\
\hline & 0.5 & $16.17 \pm 0.07$ & $14.41 \pm 0.07$ & $31.48 \pm 0.23$ \\
\hline & 0.01 & $15.77 \pm 0.11$ & $10.11 \pm 0.07$ & $20.89 \pm 0.35$ \\
\hline \multirow{3}{*}{ U2 } & 1 & $16.57 \pm 0.11$ & $16.75 \pm 0.15$ & $>$ \\
\hline & 0.5 & $15.54 \pm 0.28$ & $15.13 \pm 0.10$ & $>$ \\
\hline & 0.01 & $11.08 \pm 0.03$ & $9.87 \pm 0.02$ & $12.21 \pm 0.22$ \\
\hline \multirow{3}{*}{$\mathbf{U} 3$} & 1 & $28.27 \pm 1.39$ & $19.76 \pm 0.50$ & - \\
\hline & 0.5 & $20.72 \pm 2.58$ & $18.54 \pm 2.43$ & $38.47 \pm 0.07$ \\
\hline & 0.01 & - & - & $15.01 \pm 1.13$ \\
\hline \multirow{3}{*}{ U4 } & 1 & - & - & - \\
\hline & 0.5 & $10.82 \pm 0.05$ & $11.04 \pm 1.24$ & - \\
\hline & 0.01 & - & - & - \\
\hline \multirow{3}{*}{ U5 } & 1 & $17.58 \pm 0.09$ & $15.38 \pm 0.30$ & $>$ \\
\hline & 0.5 & $16.51 \pm 0.20$ & $15.06 \pm 0.17$ & $>$ \\
\hline & 0.01 & $10.74 \pm 0.07$ & $9.55 \pm 0.25$ & $13.49 \pm 0.20$ \\
\hline \multirow{3}{*}{ U6 } & 1 & $17.87 \pm 0.08$ & - & - \\
\hline & 0.5 & $9.88 \pm 0.01$ & - & - \\
\hline & 0.01 & - & - & - \\
\hline
\end{tabular}

$\mathrm{U} 1$ = oregano essential oil; $\mathrm{U} 2$ = tea tree essential oil; U3 = mixture of lemon, cinnamon, clove, rosemary and eucalyptus essential oils; U4 = Frankincense essential oil; U5 = basil essential oil; U6 = black pepper essential oil. Results are mean \pm SD $(n=3)$; > = without microbial growth in agar environment; - = without inhibition zones
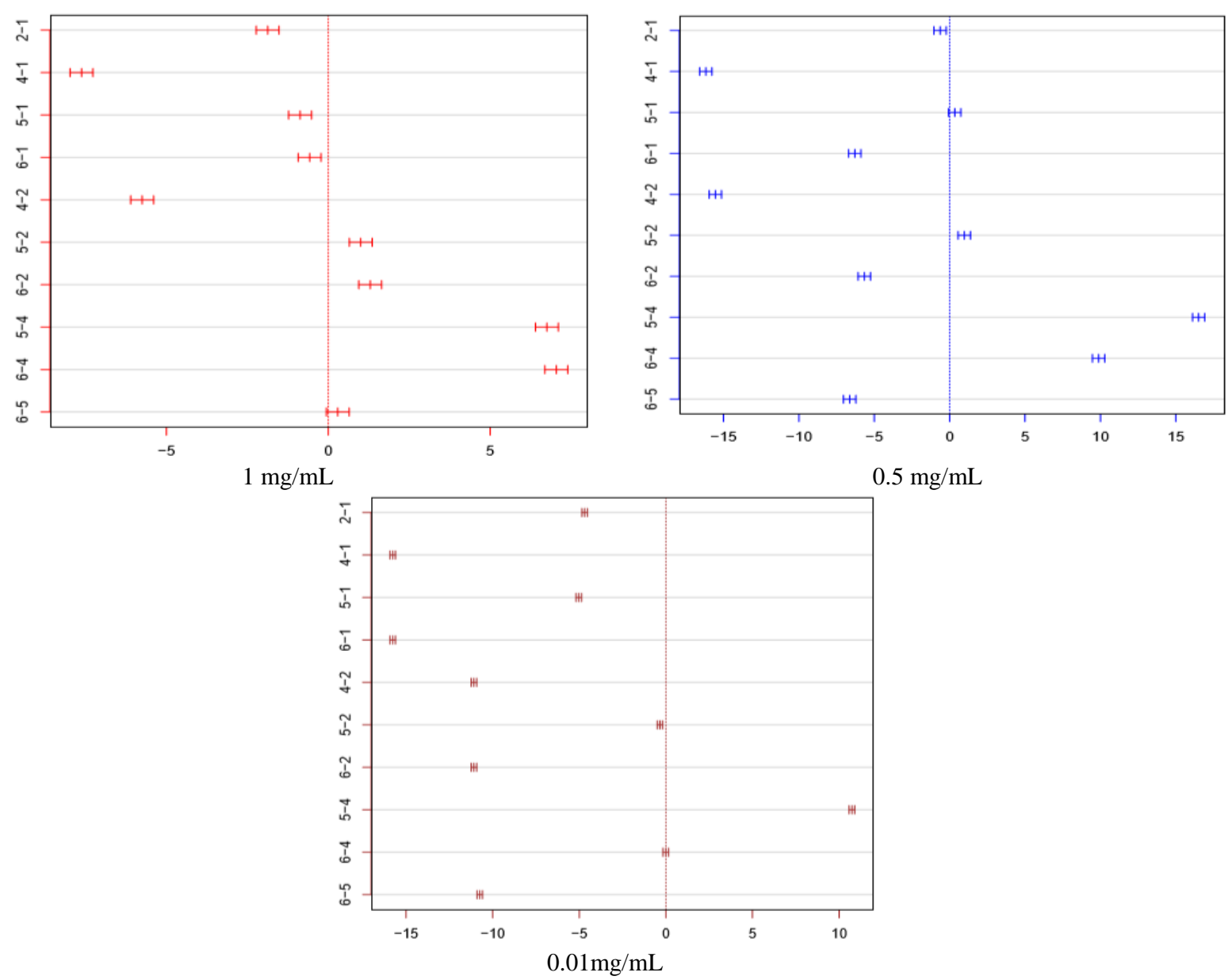

Figure 1.

The variations of the confidence intervals (CI 95\%) associated with the difference of the inhibition zones diameters means in the case of the studied essential oils, for Staphylococcus aureus strain 
FARMACIA, 2021, Vol. 69, 2
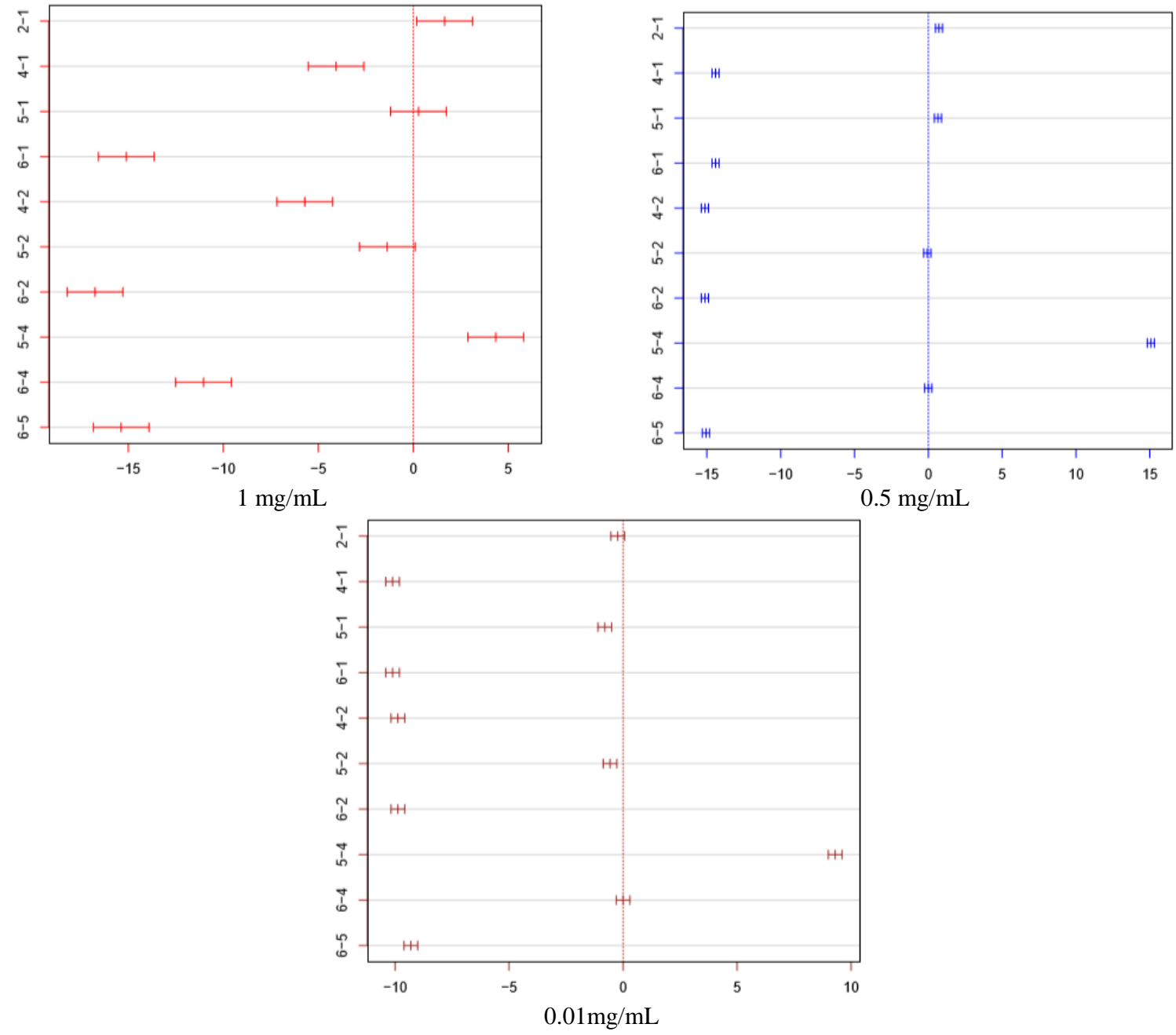

Figure 2.

The variations of the confidence intervals (CI 95\%) associated with the difference of the inhibition zones diameters means in the case of the studied essential oils, for Escherichia coli strain
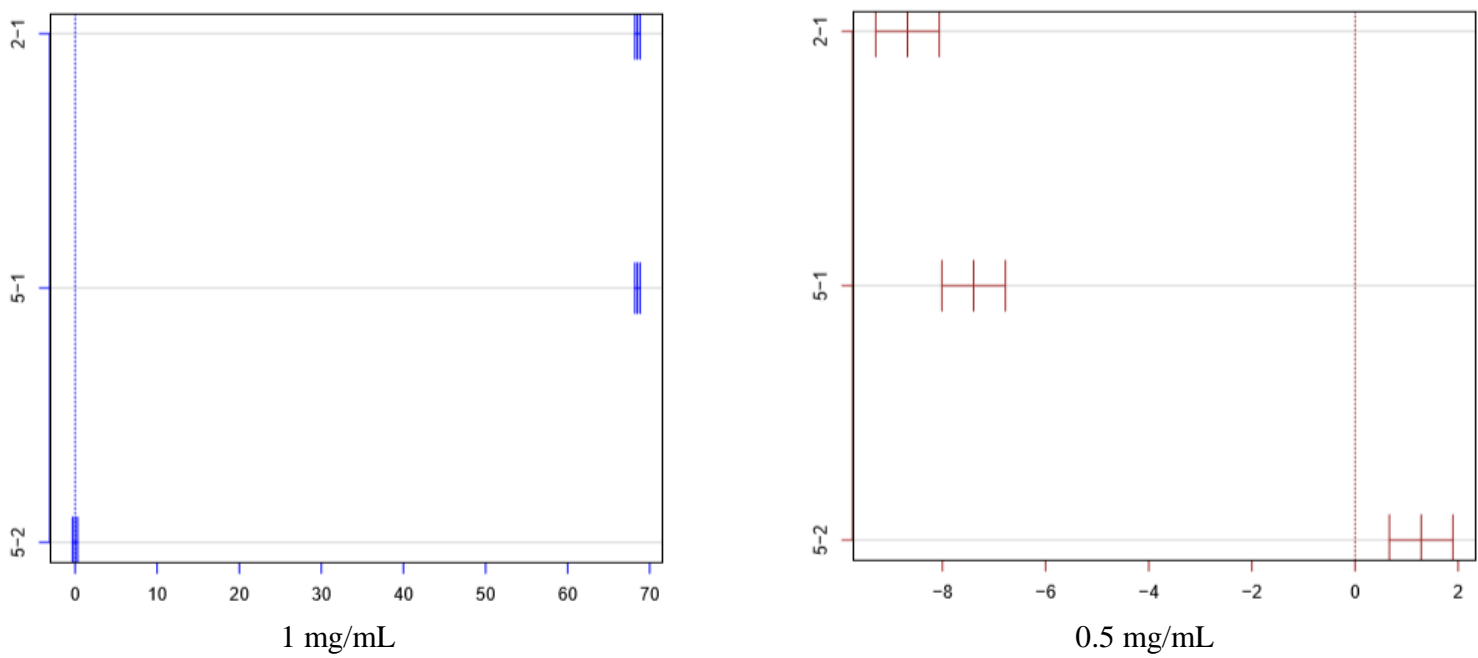

Figure 3.

The variations of the confidence intervals (CI 95\%) associated with the difference of the inhibition zones diameters means in the case of the studied essential oils, for Candida albicans

In case of Candida albicans (Figure 3) significant variations were observed, regarding the antifungal action of the studied oils. Similar activity in terms of biological effect was recorded for samples U2 and U5, 
FARMACIA, 2021, Vol. 69, 2

for all tested concentrations $(p>0.05)$. Significant differences $(\mathrm{p}<0.05)$ have been found between $\mathrm{U} 1 / \mathrm{U} 2$ and U5/U1 for $1 \mathrm{mg} / \mathrm{mL}$ and $0.01 \mathrm{mg} / \mathrm{mL}$ (Figure 3). Overall, the values of the diameters of the inhibition zones revealed important antifungal effect for U1, U2 and U5 essential oils (Table II). The highest antifungal effect, at all tested concentrations, was registered for U2 and U5 essential oils.

Therefore, according to our results, U1 (oregano) and U5 (basil) essential oils had a similar antibacterial profile against $S$. aureus, while against Escherichia coli, the antimicrobial results were similar for U1, U2 (tea tree) and U5. Moreover, tea tree and basil essential oils showed strong antifungal properties against Candida albicans.

According to the obtained data, germs' susceptibility to our samples depended on the cell wall structure. We registered a higher susceptibility of Gram-positive bacteria compared to Gram-negative bacteria or yeasts. This is easily understandable, since Gram-negative cell wall does not allow for the entrance of hydrophobic molecules as readily as Gram-positive bacteria, thus EOs are less able to affect the cell growth of the Gramnegative bacteria [37]. Our results are similar to other authors that found significant antibacterial/antifungal properties for analysed EOs [14, 24, 31, 33].

According to De Groot and Schmidt, 1,8-cineol (eucalyptol) is the main compound found in eucalyptus essential oil (62 - 98\%) together with $\alpha$-pinene, limonene, aromadendren and p-cymene. (E)-cinnamaldehyde is found in a proportion of $75 \%$ to $83 \%$ in the essential oil of Cinnamomum cassia bark, followed by eugenol and $\beta$-caryophyllene [11]. Several reports have found a synergistic effect between (E)-cinnamaldehyde and eugenol against Staphylococcus aureus [3]. Moreover, between 1,8-cineol and aromadendren, an additive potentiation interaction was observed against MSSA (methicillin-susceptible) as well as MRSA (methicillin-resistant) Staphylococcus aureus, $P$ seudomonas aeruginosa and vancomycin-resistant Enterococcus faecalis [3]. Eugenol, the main constituent found in clove essential oil (82-92\%), has shown bactericidal activity against E.coli, through alteration of membrane permeability resulting in leakage of intracellular contents [19].

Limonene is the main active compound found in lemon peel essential oil, ranging from $54 \%$ to $73 \%$. In addition to limonene, other active substances ( $\beta$ pinene, $\gamma$-terpene, $\alpha$-pinene, sabinene, geranial and neral) are also known for their antimicrobial properties. In one study, lemon essential oil demonstrated bacteriostatic properties against MSSA and E. coli [24].

According to scientific literature, rosemary essential oil contains mostly 1,8 -cineole, $\alpha$-pinene, camphor, camphene, borneol, $\beta$-pinene and limonene [11]. According to Stojiljkovic J et al. research rosemary EO has shown antibacterial activity against Gram- positive and Gram-negative bacteria (Staphylococcus aureus, Bacillus subtilis, Pseudomonas aeruginosa etc.) through various mechanisms (cytoplasm coagulation, degradation of cell wall or leakage of ions and cell contents) [37].

Based on the GC-MS certificates [40] (Table III) of the analysed EOs, we aimed to evaluate a possible correlation between the distribution of active compounds and the antimicrobial effects. One can note several constituents that are common for analysed EOs $(\alpha-$ pinene, 1.8-cineole, linalool, limonen, terpinen-4-ol etc.).

Taking into consideration our results, we assume that linalool is involved in the antibacterial effects of U1 and U5 essential oils against Staphylococcus aureus. Linalool, 3,7-dimethyl-1,6-octadien-3-ol, is a monoterpenic compound found in the composition of many essential oils, which has the ability to alter the permeability and function of cell membrane proteins by penetrating the phospholipid layer of the bacterial cell wall and binding to the membrane proteins $[23,34]$. The attendance of linalool in the composition of essential oils can significantly improve the antimicrobial activity, due to a synergistic effect [23]. According to Herman A et al. work a synergistic effect between linalool and clove essential oil was observed against Staphylococcus aureus, Escherichia coli, Pseudomonas aeruginosa and Candida albicans strains [18]. Regarding our samples, aerial parts of Origanum vulgare subsp. vulgaris, also known as common oregano, contain up to $1.8 \%$ essential oil, which is lower compared to other Origanum vulgare subspecies. Still, according to some authors, Origanum vulgare subspecies, with a medium or low EO content, generally have higher concentrations of linalool [7]. As seen in Table III, for our experiments, we have used certified organic basil essential oil, from Nepal, which contains $65.2 \%$, linalool, similar to the European type of basil, with a linalool content in the range $35 \%-50 \%$ [34].

Against Escherichia coli, the antimicrobial results were similar for U1, U2 and U5. As depicted in Table III, the oregano and tea tree EOs contain $\alpha$-pinene, $p$ cymene, $\alpha$-terpinene and $\gamma$-terpinene. Similar compounds found in basil essential oil and oregano/tea tree EOs include 1,8-cineole, linalool and terpinen-4-ol.

According to recent research, 1,8-cineole is the most effective compound of tea tree oil against the integrity of the bacteria membrane. Thus, 1,8-cineole might increase the permeability of the bacteria membrane, thus facilitating the penetration of other compounds that target the bacterial respiration or the expression of genes involved in the formation of microbial biofilms [5, 6]. According to our statistical analysis, tea tree essential oil (U2) has an antimicrobial behaviour similar to basil (U5) EO, due to the common content of terpinen-4-ol (39.6\% for U2 and $1.6 \%$ for U5) and 1,8-cineole (3.9\% for $\mathrm{U} 2$ and $3.6 \%$ for $\mathrm{U} 5$ ). 
Chemical composition of analysed EOs (according to GC-MS certificates) [40]

\begin{tabular}{|c|c|c|c|c|c|}
\hline Compound (\%) & U1 & U2 & U4 & U5 & U6 \\
\hline$\alpha$-pinene & 1.20 & 2.70 & 5 & & \\
\hline 1,8-cineole & & 3.90 & & 3.60 & \\
\hline limonene & & 1.10 & 2 & & 18.40 \\
\hline linalool & 1.50 & & & 65.20 & \\
\hline p-cymene & 9.40 & 3.90 & 1.90 & & \\
\hline sabinene & & 0.20 & 5.90 & & 12.60 \\
\hline terpinen-4-ol & & 39.60 & & 1.60 & \\
\hline$\alpha$-terpinene & 1.20 & 8.60 & & & \\
\hline$\gamma$-terpinene & 6.50 & 20.90 & & & \\
\hline$\alpha$-thujene & 1.30 & & 68.30 & & 1.60 \\
\hline$\beta$-caryophyllene & 2.50 & & & & 17.90 \\
\hline$\gamma$-cadinene & & & & 1.60 & 3.40 \\
\hline$\delta$-cadinene & & 0.90 & & & 1.80 \\
\hline$\Delta 3$-carene & & & 3.40 & & 3.80 \\
\hline$\Delta$-elemene & & & & & 1.20 \\
\hline$\alpha$-copaene & & & & & 3.80 \\
\hline$\beta$-pinen & & & & & 10.40 \\
\hline$\alpha$-terpineol & & 2.90 & & & \\
\hline viridiflorol & & 0.20 & & & \\
\hline viridiflorene & & 0.70 & & & \\
\hline terpinolene & & 3.30 & & & \\
\hline globulol & & 0.40 & & & \\
\hline aromadendrene & & 1 & & & \\
\hline thymol & 4 & & & & \\
\hline carvacrol & 65.80 & & & & \\
\hline T-cadinol & & & & 1.60 & \\
\hline trans- $\alpha$-bergamotene & & & & 3 & \\
\hline eugenol & & & & 3.20 & \\
\hline geraniol & & & & 4.70 & \\
\hline germacrene D & & & & 2.20 & \\
\hline$\alpha$-phelandrene & & & 2.60 & & \\
\hline methylchavicol & & & 2.70 & & \\
\hline
\end{tabular}

The results of the statistical analysis corroborated with the content of 1,8-cineole support the hypothesis that this compound increases the permeability of the microbial membrane with antimicrobial effects $[5,6]$. Another important compound of the tea tree essential oil is $\alpha$-pinene, which is much more effective than terpinen-4-ol in inhibiting the formation of microbial biofilms by Qvorum sensing (a process of intercellular signalling and a vital regulatory mechanism for coordinating biofilm formation) [21].

p-Cymene is the major compound of many plant extracts and essential oils used in traditional medicine for their antimicrobial action, but also the common compound of oregano (U1) and tea tree (U2) EOs. We assume that p-cymene is responsible for the antibacterial activity against Escherichia coli, incriminated for reducing the microbial films formation [25]. According to the current research, $\mathrm{p}$-cymene intensifies the antimicrobial activity of other constituents (such as carvacrol or terpinen-4-ol) [25].

Additionally the higher concentrations of $\alpha$-terpinene (8.60\%) and $\gamma$-terpinene $(20.90 \%)$ found in U2 essential oil, compared to p-cymene $(3.90 \%)$, suggest that the oil was properly stored and did not undergo chemical changes [6]. According to Cristiani M et al. $\gamma$-terpinene also showed antimicrobial activity towards E. coli. Still, the antimicrobial effect was much lower compared to thymol, carvacrol or p-cymene [10].

Common compounds possibly responsible for the similar antibacterial behaviour of U4 and U6 essential oils against Escherichia coli and Staphylococcus aureus are $\alpha$-thujene, sabinene, $\Delta 3$-caren, alpha-pinene and limonene [8, 35]. The research of Kerekes EB et al. has highlighted anti-biofilm properties in the case of $\alpha$-pinene and limonene. The targets of these compounds are the cell wall and the cytoplasmic membrane of bacteria or the membrane proteins. The loss of cellular components caused by loss of cell membrane integrity can lead to bacterial cell death. Impaired cell membrane integrity is also correlated with the loss of the bacterium's ability to attach to surfaces and to form bacterial biofilms [21, 35].

Regarding the antifungal activity against Candida albicans, a significant activity was found for the tea tree (U2) and basil (U5) EOs and this effect is probably due to 1,8-cineole and terpinen-4-ol contents. In an 
experimental model of vaginal candidosis in rats, terpinen-4-ol was as effective as tea tree essential oil in eradicating the infection, emphasizing the importance of this compound as an antifungal agent. In vitro, MFC (minimum fungicidal concentrations) were determined for terpinen-4-ol, 1,8-cineole and tea tree essential oil. The MFC were $0.06 \%$ (v/v) (for terpinen-4-ol), $4 \%$ $(\mathrm{v} / \mathrm{v})$ (for 1,8 cineole) and $0.25 \%(\mathrm{v} / \mathrm{v})$ (for tea tree oil) [26].

\section{Conclusions}

According to our results, oregano, tea tree and basil essential oils have shown significant antimicrobial activity towards Gram-positive (Staphylococcus aureus), Gram-negative (Escherichia coli) and yeasts (Candida albicans). The samples which exerted significant activity against $S$. aureus presented linalool as a regular constituent. The essential oils that proved significant effect against E. coli contained linalool, 1,8-cineole, terpinen-4-ol, $\alpha$-pinene, $\mathrm{p}$-cymene, $\alpha / \gamma$ terpinene as common active principals, while Candida albicans was susceptible to 1,8-cineole and terpinen4-ol. Nevertheless, plant extracts should be regarded from the perspective of a phytocomplex with synergistic value owed to each active molecule.

\section{Conflict of interest}

The authors declare no conflict of interest.

\section{References}

1. Albeanu G, Ghica M, Popentiu-Vladicescu F, On using bootstrap scenario-generation for multi-period stochastic programming applications. Int J Comp Communic Contr., 2008; 3: 156-161.

2. Ayari S, Shankar S, Follett P, Hossain F, Lacroix $\mathrm{M}$, Potential synergistic antimicrobial efficiency of binary combinations of essential oils against Bacillus cereus and Paenibacillus amylolyticus - Part A. Microb Pathog., 2020; 141: 104008.

3. Bassolé IHN, Juliani HR, Essential Oils in Combination and Their Antimicrobial Properties. Molecules, 2012; 17(4): 3989-4006.

4. Bhavaniramya S, Vishnupriya S, Al-Aboody MS, Vijayakumar R, Baskaran D, Role of essential oils in food safety: Antimicrobial and antioxidant applications. Grain Oil Sci Technol., 2019; 2(2): 49-55.

5. Boyko NN, Zhilyakova ET, Pisarev DI, Novikov OO, Sahaidak-Nikitiuk RV, Kuznietsova VY, Shpychak OS, Tkachev AV, Kovalenko AM, Sushchuk NA, A novel method for the extraction of the main compounds from the essential oil of clove buds. Farmacia, 2020; 68(1): 170-175.

6. Brun P, Bernabè G, Filippini R, Piovan A, In Vitro Antimicrobial Activities of Commercially Available Tea Tree (Melaleuca alternifolia) Essential Oils. Curr Microbiol., 2018; 76(1): 108-116.

7. Burlec AF, Macovei I, Săcărescu A, Corciovă A, Mircea C, Iancu CE, Cioancă O, Hăncianu M, Essential oils in wellness centers: overview on European Union legislation, potential therapeutic effects and toxicity. Farmacia, 2020; 68(6): 992-998.

8. Cao B, Wei XC, Xu XR, Zhang HZ, Luo CH, Feng B, Xu RC, Zhao SY, Du XJ, Han L, Zhang DK, Seeing the Unseen of the Combination of Two Natural Resins, Frankincense and Myrrh: Changes in Chemical Constituents and Pharmacological Activities. Molecules, 2019; 24(3076): 1-27.

9. Chouhan S, Sharma K, Guleria S, Antimicrobial activity of some essential oils-present status and future perspectives. Medicines (Basel), 2017; 4(3): 58: 1-21.

10. Cristani M, D'Arrigo M, Mandalari G, Castelli F, Sarpietro MG, Micieli D, Venuti V, Bisignano G, Saija A, Trombetta D, Interaction of four monoterpenes contained in essential oils with model membranes: implications for their antibacterial activity. J Agric Food Chem., 2007; 55(15): 6300-6308.

11. de Groot AC, Schmidt E, Essential Oils, Part III: Chemical Composition. Dermatitis, 2016; 27(4): 161169.

12. Devi KP, Nisha SA, Sakthivel R, Pandian SK, Eugenol (an essential oil of clove) acts as an antibacterial agent against Salmonella typhi by disrupting the cellular membrane. J Ethnopharmacol., 2010; 130: 107-115.

13. Di L, Fish PV, Mano T, Bridging solubility between drug discovery and development. Drug Discov Today, 2012; 17(9-10): 486-495.

14. Di Vito M, Fracchiolla G, Mattarelli P, Modesto M, Tamburro A, Padula F, Agatensi L, Giorlandino FR, Girolamo A, Carbonara GG, Carrieri A, Corbo F, Mondello F, Probiotic and tea tree oil treatments improve therapy of vaginal candidiasis: a preliminary clinical study. Med J Obstet Gynecol., 2016; 4(4): $1-6$.

15. Dhifi W, Bellili, S, Jazi S, Bahloul N, Mnif W, Essential oils' chemical characterization and investigation of some biological activities: A critical review. Medicines, 2016; 3(4): 25: 1-16.

16. Georgescu M, Ginghina O, Raita S, Tapaloaga D, Ilie L, Negrei C, Popa DE, Varlas V, Multescu R, Rosca AC, Mirica R, Georgescu D, Natural alternative remedies in the background of updated recommendations for the prophylactic and therapeutic approach of Clostridium difficile infections. Farmacia, 2018; 66(4): 563-572.

17. Guenther E, The Essential Oils—Vol 1: HistoryOrigin in Plants - Production-Analysis. Read Books Ltd., Redditch, UK, 2013.

18. Herman A, Tambor K, Herman A, Linalool Affects the Antimicrobial Efficacy of Essential Oils. Curr Microbiol., 2016; 72(2): 165-172.

19. Jeyakumar GE, Lawrence R, Mechanisms of bactericidal action of Eugenol against Escherichia coli. J Herb Med., 2021; 26: 100406.

20. Jovanka L, Ivana C, Goran T, Sava P, Slavica S, Tamara CG, Ljiljana KO, In vitro antibacterial activity of essential oils from plant family Lamiaceae. Rom Biotech Lett., 2011; 16(2): 6034-6041.

21. Kerekes EB, Deak E, Tako M, Tserennadmid R, Petkovits T, Vagvolgyi C, Krisch J, Anti-biofilm forming and anti-quorum sensing activity. J Appl Microbiol., 2013; 115(4): 933-942. 
22. Mair P, Wilcox R, Robust Statistical Methods in R Using the WRS2 Package. Behav Res Methods, 2020; 52(2): 464-488.

23. Man A, Gâz AŞ, Mare AD, Berţa L, Effects of lowmolecular weight alcohols on bacterial viability. Rev Romana Med Lab., 2017; 25(4): 335-343.

24. Man A, Santacroce L, Iacob R, Mare A, Man L, Antimicrobial Activity of Six Essential Oils Against a Group of Human Pathogens: A Comparative Study. Pathogens, 2019; 8(15): 1-11.

25. Marchese A, Arciola CR, Barbieri R, Sanches Silva A, Nabavi SF, Tsetegho AJS, Izadi M, Jafari NJ, Suntar I, Daglia M, Update on Monoterpenes as Antimicrobial Agents: A Particular Focus on p-Cymene. Materials, 2017; 10(8): 947: 1-15.

26. Mondello F, De Bernardis F, Girolamo A, Cassone A, Salvatore G, In vivo activity of terpinen-4-ol, the main bioactive component of Melaleuca alternifolia Cheel (tea tree) oil against azole-susceptible and resistant human pathogenic Candida species. BMC Infect Dis., 2006; 6(158): 1-8.

27. Nazzaro F, Fratianni F, Coppola R, Feo VD, Essential oils and antifungal activity. Pharmaceuticals, 2017; 10(4): 86: 1-20.

28. NCLS 2002. Performance standards for antimicrobial susceptibility testing. In: $12^{\text {th }}$ International Supplement, M100-S12. National Comitee for Clinical Laboratory Standards, Wayne, Pennsylvania, USA.

29. Pierozan M K, Pauletti GF, Rota L, Santos ACAD, Lerin LA, Di Luccio M, Oliveira JV, Chemical characterization and antimicrobial activity of essential oils of Salvia L. species. Food Sci Technol., 2009; 29(4): 764-770.

30. Pinto E, Salgueiro LR, Cavaleiro C, Palmeira A, Gonçalves MJ, In vitro susceptibility of some species of yeasts and filamentous fungi to essential oils of Salvia officinalis. Ind Crops Prod., 2007; 26(2): 135141.

31. Puškárová A, Bučková M, Kraková L, Pangallo D, Kozics K, The antibacterial and antifungal activity of six essential oils and their cyto/genotoxicity to human HEL 12469 cells. Sci Rep., 2017; 7(1): 1-11.

32. Rao J, Chen B, McClements DJ, Improving the efficacy of essential oils as antimicrobials in foods: Mechanisms of action. Annu Rev Food Sci Technol., 2019; 10: 365-387.

33. Sakkas H, Gousia P, Economou V, Sakkas V, Petsios $\mathrm{S}$, Papadopoulou $\mathrm{C}$, In vitro antimicrobial activity of five essential oils on multidrug resistant gramnegative clinical isolates. $J$ Intercult Ethnopharmacol., 2016; 5(3): 212-218.

34. Sakkas H, Papadopoulou C, Antimicrobial Activity of Basil, Oregano, and Thyme Essential Oils. J Microbiol Biotechnol., 2017; 27(3): 429-438.

35. Salehi B, Zakaria ZA, Gyawali R, Ibrahim SA, Rajkovic J, Shinwari ZK, Khan T, Sharifi-Rad J, Ozleyen A, Turkdonmez E, Valussi M, Tumer TB, Fidalgo LM, Martorell M, Setzer WN, Piper Species: A Comprehensive Review on Their Phytochemistry, Biological Activities and Applications. Molecules, 2019; 24(1364): 1-118.

36. Sharifi-Rad J, Sureda A, Tenore GC, Daglia M, Sharifi-Rad M, Valussi M, Tundis R, Sharifi-Rad M, Loizzo MR, Ademiluyi AO, Sharifi-Rad R, Ayatollahi SA, Iriti M, Biological Activities of Essential Oils: From Plant Chemoecology to Traditional Healing Systems. Molecules (Basel, Switzerland), 2017; 22(1): 70: $1-55$.

37. Stojiljkovic J, Trajchev M, Nakov D, Petrovska M, Antibacterial activities of rosemary essential oils and their components against pathogenic bacteria. $A d v$ Cytol Pathol., 2018; 3(4): 93-96.

38. Teixeira B, Marques A, Ramos C, Neng NR, Nogueira JM, Saraiva JA, Nunes ML, Chemical composition and antibacterial and antioxidant properties of commercial essential oils. Ind Crops Prod., 2013; 43: 587-595.

39. Tongnuanchan P, Benjakul S, Essential oils: Extraction, bioactivities, and their uses for food preservation. $J$ Food Sci., 2014; 79: R1231-R1249.

40. www.planttherapy.com. 